\title{
PENGEMBANGAN MODUL INTERAKTIF BERBASIS MULTIPLE INTELLIGENCE DENGAN AUTOPLAY PADA KONSEP PERUBAHAN MATERI GENETIK DI IKIP BUDI UTOMO MALANG
}

\author{
Khoirun Nisa ${ }^{1}$, Deny Setiawan², \\ ${ }^{1}$ Pendidikan Biologi IKIP Budi Utomo Malang \\ Jalan Simpang Arjuno 14B Malang \\ ${ }^{2}$ Pendidikan Biologi, Universitas Negeri Malang \\ Jalan Semarang No 5 Malang \\ E-mail: khoirunisaq@gmail.com
}

\begin{abstract}
Technology-based learning needs to be done immediately in order to carry out more interested in learning and fostering student motivation. Furthermore, learning should be done by each student characteristics. One of which is multiple intelligences based learning. Through the application of multiple intelligence assisted technology based learning, it is expected that the learning objectives will be more easily achieved by students. Interactive module based on multiple intelligences that has been validated was the product of this research and developmental experiment. This research was limited to the Changes of Genetic Material taught at the Genetics Course at IKIP Budi Utomo Malang. Research and development model was carried out by 4D model from Thiagarajan (1974). This research phase includes define, design, design, and disseminate stages. The research data is obtained from the module validation score, both from material experts, media experts, and practitioners (students). The data obtained were analyzed qualitatively and quantitatively. Based on the results of the validation of media experts, material experts and small-scale trials, it is known that the percentage results are above $85 \%$, so the product is declared valid. Furthermore, it is necessary to test the classical scale to find out its effectiveness in learning.
\end{abstract}

Keywords: Interactive Module, Multiple Intelligences, Autoplay, Changes in Genetic Material.

\section{PENDAHULUAN}

Perkembangan yang sangat pesat dalam bidang teknologi untuk pendidikan telah mengubah metode pembelajaran dari pembelajaran konvensional menjadi pembelajaran yang memanfaatkan teknologi. Komputer, smartphone, atau pc tablet sudah bukan menjadi barang mewah lagi. Alat-alat tersebut diharapkan akan lebih bermanfaat jika dapat digunakan dengan baik. Salah satu langkah yang dapat dilakukan adalah dengan mengintegrasikan teknologi tersebut ke dalam kegiatan pembelajaran di kelas.

Penerapan teknologi di IKIP Budi Utomo sudah bukan merupakan hal baru. Mahasiswa sudah mulai terbiasa untuk belajar secara langsung dari internet, mencari literatur, dan menemukan jawaban atas permasalahan mereka di internet. Namun, ketersediaan bahan ajar yang memanfaatkan teknologi masih sangat terbatas. Sehingga perlu adanya alternatif bahan ajar berbasis 
teknologi untuk mengakomodasi kebutuhan mahasiswa di IKIP Budi Utomo Malang.

Sebuah kegiatan pembelajaran akan lebih bermakna jika mahasiswa mengetahui konsep apa yang dipelajarinya. Akan tetapi dalam memahami sebuah konsep, tidak jarang mahasiswa mengalami kesulitan dalam mempelajarinya. Salah satunya adalah materi perubahan materi genetik pada matakuliah Genetika. Genetika adalah salah satu matakuliah wajib yang ada di Program Studi Pendidikan Biologi di IKIP Budi Utomo Malang. Dalam kajiannya selama pembelajaran, konsep perubahan materi genetik cenderung sulit dipahami oleh mahasiswa. Oleh karena itu, diperlukan suatu alat bantu untuk dapat menjelaskan konsep tersebut lebih baik lagi. Penggunaan modul adalah salah satu alternatif dalam membantu mahasiswa untuk belajar baik secara mandiri atau kelompok.

Modul merupakan bahan ajar yang disusun secara sistematis, dengan bahasa yang mudah dipahami oleh mahasiswa, sesuai usia dan tingkat pengetahuan mereka agar mereka dapat belajar secara mandiri dengan bimbingan minimal dari pendidik (Prastowo, 2012). Hal ini berarti bahwa kemampuan individu mahasiswa diharapkan berkembang sesuai dengan kemampuan masing-masing. Pemanfaatan modul dalam pembelajaran sebelumnya sudah diterapkan dalam matakuliah genetika karena modul memiliki keunggulan dalam mewujudkan pembelajaran yang efektif, efisien dan relevan (Wena, 2009).

Selain menggunakan modul, karakter mahasiswa juga menjadi salah satu pertimbangan dalam memberdayakan pembelajaran secara maksimal. Kemampuan yang dimiliki mahasiswa pada dasarnya pasti memiliki perbedaan. Setiap mahasiswa memiliki kemampuan unik yang tidak dapat disamakan dengan mahasiswa lainnya. Konsep ini dikenal dengan konsep kecerdasan majemuk atau multiple intelligence.

Gardner (2010) mengemukakan konsep Multiple Intelligence bahwa sebenarnya manusia memiliki beberapa jenis kecerdasan. Lebih lanjut, Gardner (2003) mengelompokkan kecerdasan manusia kedalam sembilan kecerdasan. Setiap manusia pasti memiliki lebih dari satu kecerdasan, sehingga disebut kecerdasan majemuk, tetapi masing-masing hanya memiliki satu atau beberapa aspek yang paling menonjol. Kesembilan kecerdasan itu adalah kecerdasan verbal-linguistik, kecerdasan logika-matematika, kecerdasan kinestetik, kecerdasan spasial, kecerdasan bermusik, kecerdasan interpersonal, kecerdasan intrapersonal, kecerdasan naturalis, dan kecerdasan eksistensial.

Menurut Gardner (2003), peserta didik diketahui lebih mudah belajar atau memahami bahan yang diajarkan pendidik apabila bahan tersebut disajikan sesuai dengan kecerdasan peserta didik yang menonjol. Melalui modul yang sesuai dengan kecerdasan masing-masing mahasiswa, diharapkan kemampuan mahasiswa dapat lebih maksimal dalam memahami konsepkonsep yang ada pada Matakuliah Genetika.

Berangkat dari permasalahan tersebut, maka perlu untuk dikembangkan modul interaktif berbasis Multiple Intelligence. Modul ini dapat diwujudkan dengan memanfaatkan media Autoplay Media Studio. Autoplay merupakan perangkat lunak untuk membuat perangkat lunak multimedia dengan mengintegrasikan berbagai tipe media yang disediakan, misalnya gambar, suara, video, teks dan flash ke dalam presentasi yang dibuat. Autoplay selain memiliki fitur yang cukup lengkap, kualitas 
media yang dihasilkan juga sangat bagus. Sehingga media ini sesuai untuk digunakan dalam pengembangan modul interaktif ini.

\section{METODE PENELITIAN}

Langkah penelitian ini dilakukan berdasarkan pengembangan konseptual yang direkomendasikan oleh Thiagarajan dkk. (1974) yang disebut model 4D. Model ini meliputi tahap Define, Design, Develop, dan Disseminate. Tahap define mencakup lima langkah pokok, yaitu analisis ujung depan, analisis siswa, analisis tugas, analisis konsep dan perumusan tujuan pembelajaran. Tahap define dilakukan dengan melakukan observasi kelas dan wawancara pada dosen Genetika. Tahap design dilakukan dalam empat langkah yaitu: (1) penyusunan standar tes, (2) pemilihan media, (3) pemilihan format, (4) membuat rancangan awal. Tahap develop adalah tahap untuk menghasilkan produk pengembangan yang dilakukan melalui penilaian oleh ahli. Pada penelitian ini belum dilakukan proses diseminasi karena keterbatasan waktu pelaksanaan penelitian.

Data didapatkan melalui media angket yang dikembangkan oleh Sungkono (2015). Jenis data yang dihasilkan adalah data kualitatif dan data kuantitatif. Data kualitatif adalah saran ataupun kritik yang dituliskan oleh validator. Data kuantitatif adalah data yang berasal dari angket yang berisi rating scale. Angket ini berisi kolomkolom yang menunjukkan tingkatannya. Jawaban angket dengan menggunakan angka Likert dengan lima kategori pilihan yaitu angka 5 berarti sangat baik, angka 4 berarti baik, angka 3 berarti cukup, angka 2 berarti kurang baik, dan angka 1 berarti tidak baik.

Analisis data kualitatif mengacu pada hasil saran, kritik atau komentar dari validator. Saran yang dapat Saran atau komentar yang diberikan oleh validator tersebut dapat ditindaklanjuti atau dapat tidak ditindaklanjuti. Tindak lanjut ini tergantung dari dapat dilakukan atau tidaknya perbaikan tersebut.

Analisis data kuantitatif dilakukan berdasarkan hasil angket penilaian instrumen dengan skala Likert dan dianalisis dengan analisis persentase. Penilaian dilakukan dengan menggunakan rumus berikut.

$$
P=\frac{\sum x i}{\sum x j} \times 100 \%
$$

Keterangan:

$\mathrm{P} \quad$ : Taraf Persentase

$\sum x i$ : jumlah skor penilaian

$\sum x j$ : skor maksimal

Berdasarkan hasil nilai persentase tersebut, selanjutnya dibandingkan dengan jenjang kualifikasi penilaian pada Tabel 1 . untuk menentukan kriteria dari instrumen dan keperluan revisi produk.

Tabel 1. Jenjang Kualifikasi Penilaian Instrumen

\begin{tabular}{cccc}
\hline $\begin{array}{c}\text { Taraf } \\
\text { Persentase } \\
(\boldsymbol{\%})\end{array}$ & $\begin{array}{c}\text { Keteran } \\
\text { gan }\end{array}$ & $\begin{array}{c}\text { Kriteria } \\
\text { Validitas }\end{array}$ & $\begin{array}{c}\text { Ketera } \\
\text { ngan }\end{array}$ \\
\hline $84-100$ & $\begin{array}{c}\text { Sangat } \\
\text { Baik }\end{array}$ & Valid & Tidak \\
& Baik & Cukup Valid & $\begin{array}{c}\text { Revisi } \\
62-<84\end{array}$ \\
$41-<61$ & Kurang & Kurang Valid & Revisi \\
& Baik & & \\
$<41$ & Tidak & Tidak Valid & Revisi \\
& Baik & & \\
\hline
\end{tabular}

Dimodifikasi dari Setiawan (2012)

\section{HASIL DAN PEMBAHASAN}

\section{Hasil Tahap Define}

Pada tahap analisis ujung depan (front-end analysis) dilakukan dengan menetapkan masalah dasar yang dihadapi oleh mahasiswa selama kegiatan pembelajaran. Berdasarkan hasil analisis, diketahui bahwa mahasiswa mengalami kesulitan dalam memahami konsep-konsep pada matakuliah Genetika. Hal ini terjadi karena sebagian besar materi yang bersifat abstrak, sehingga perlu adanya 
penggambaran yang jelas dari sebuah konsep yang dipelajari. Mahasiswa membutuhkan video materi pembelajaran atau kegiatan pembelajaran yang bersifat interaktif untuk mempermudah mahasiswa dalam memahami konsep. Masalah ini juga ditemukan oleh Darmawan (2016), yang menyebutkan bahwa kesulitan yang sering dihadapi oleh guru biologi adalah sulitnya pemberian contoh pada materi yang bersifat abstrak, sehingga berdampak pada pemahaman konsep siswa.

Analisis siswa dilakukan dengan menyebarkan angket kecerdasan majemuk yang dikembangkan oleh Gardner (2010) kepada mahasiswa. Berdasarkan angket yang sudah diisi mahasiswa diperoleh data sebaran kecerdasan majemuk seluruh mahasiswa Pendidikan Biologi IKIP BUDI UTOMO MALANG angkatan 2016 dan 2017 dapat diketahui pada Tabel 2.

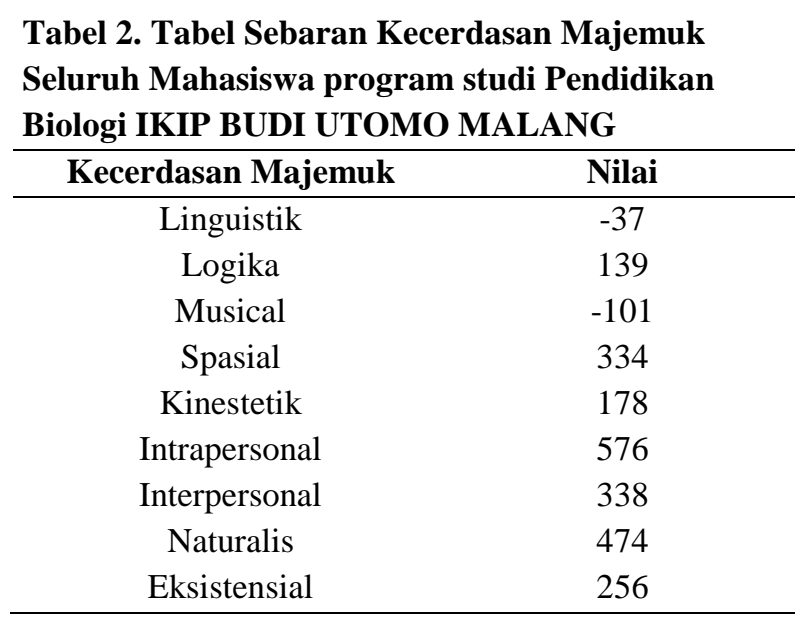

Berdasarkan hasil analisis angket diperoleh bahwa ada 2 kecerdasan majemuk dominan yang dimiliki oleh mahasiswa prodi pendidikan Biologi yaitu; kecerdasan Intrapersonal dan kecerdasan Naturalis. Hal ini dapat diartikan bahwa secara umum pembelajaran di prodi Pendidikan Biologi IKIP Budi Utomo dapat dilakukan dengan menerapkan pembelajaran yang menggunakan kecerdasan Intrapersonal dan kecerdasan Naturalis.
Kecerdasan Intrapersonal adalah kemampuan yang berkaitan dengan pengetahuan terhadap diri sendiri dan kemampuan untuk bertindak secara adaptif dari diri sendiri (Machali, 2014). Hal ini berarti mahasiswa Prodi Pendidikan Biologi IKIP Budi Utomo lebih dominan dalam bekerja secara mandiri untuk menemukan konsep yang dipelajarinya. Kegiatan pembelajaran seperti merangkum, merefleksi pembelajaran secara mandiri merupakan salah satu contoh kegiatan pembelajaran yang bisa digunakan sebagai alternatif dalam pembelajaran. Herawati (2018) menjelaskan lebih lanjut bahwa kecerdasan intrapersonal adalah kemampuan untuk berpikir secara reflektif. Kegiatan yang dapat dilakukan untuk mengembangkannya adalah melakukan kegiatan refleksi, self analisis, sehingga terbentuk citra diri yang positif.

Kecerdasan kedua yang paling dominan adalah kecerdasan naturalis. Kecerdasan naturalis adalah kecerdasan untuk memahami alam dan menggunakan kemampuan tersebut secara produktif (Machali, 2014). Kecerdasan Naturalis pada mahasiswa prodi pendidikan biologi terhitung salah satu yang dominan karena keterikatan mahasiswa dengan konsep yang dipelajari oleh mahasiswa. Mahasiswa sudah mempelajari dan mendalami ilmu alam sebagai ilmu yang dipilih oleh mahasiswa tersebut.

Analisis konsep (concept analysis) dilakukan dengan mengidentifikasi konsep pokok yang akan diajarkan dalam kegiatan pembelajaran, menyusun dalam bentuk hirarki, dan merinci kedalam indikator dan tujuan pembelajaran yang terukur. Mendukung analisis konsep ini, analisisanalisis yang perlu dilakukan adalah (1) analisis standar kompetensi dan kompetensi dasar yang bertujuan untuk menentukan 
jumlah dan jenis bahan ajar, (2) analisis sumber belajar, yakni mengumpulkan dan mengidentifikasi sumber-sumber mana yang mendukung penyusunan bahan ajar. Pada analisis konsep yang dilakukan, ditentukan kompetensi yang akan dicapai oleh mahasiswa. Kompetensi yang diharapkan adalah mahasiswa menjelaskan konsep perubahan materi genetik.

Pada tahap analisis tugas (task analysis) dilakukan dengan mengidentifikasi keterampilan-keterampilan utama yang akan dikaji oleh peneliti dan menganalisisnya kedalam himpunan keterampilan tambahan yang mungkin diperlukan. Analisis ini memastikan ulasan yang menyeluruh tentang tugas dalam materi pembelajaran. Kegiatan pembelajaran berdasar pada 9 kecerdasan majemuk dari Howard Gardner.

Analisis perumusan tujuan pembelajaran menurut Thiagarajan, dkk (1974) dilakukan untuk merangkum hasil dari analisis konsep dan analisis tugas untuk menentukan perilaku terhadap objek penelitian. Kumpulan objek tersebut menjadi dasar untuk menyusun tes dan merancang perangkat pembelajaran. Selanjutnya diintegrasikan ke dalam materi perangkat pembelajaran yang akan digunakan oleh peneliti. Hasil dari perumusan tujuan ini adalah mahasiswa mampu menjelaskan konsep perubahan materi genetik dengan pembelajaran berbasis kecerdasan majemuk melalui media interaktif.

\section{Hasil Tahap Design}

Media yang dipilih untuk mengoptimalkan penggunaan media dalam proses pengembangan bahan ajar pada pembelajaran di kelas. Media yang dipilih adalah media berbasis elektronik. Hal ini dipilih untuk meningkatkan motivasi belajar mahasiswa dalam memahami konsep sesuai dengan kecerdasan yang dimiliki. Program yang digunakan untuk membantu proses pengembangan media adalah Autoplay Media Studio. Media yang tepat sangat dibutuhkan oleh mahasiswa untuk mengakomodasi jenis materi yang sulit oleh sebagian mahasiswa dalam menerima informasi atau materi (Anantyarta dan Sari, 2017).

Format dalam produk yang dikembangkan berbasis interaktif. Mahasiswa memilih modul sesuai dengan kemampuan kecerdasannya yang paling tinggi. Untuk menentukan kecerdasan yang paling tinggi dapat dilakukan dengan Howard Gardner Multiple Intelligence Test. Kegiatan pembelajaran dari masing masing kecerdasan spesifik untuk kegiatan pembelajaran.

Pada tahap Rancangan awal telah didapatkan modul yang siap untuk divalidasi. Produk yang dikembangkan adalah modul perubahan materi genetik dengan memanfaatkan Autoplay Media Studio yang bersifat interaktif. Selain itu petunjuk penggunaan media juga dibuat untuk membantu mempermudah dalam proses pembelajaran.

\section{Hasil Tahap Develop}

Hasil tahap develop diketahui berdasarkan hasil validasi ahli materi dan ahli media pada beberapa aspek. Hasil validasi ahli materi dapat diketahui pada Tabel 3.

Tabel 3 Hasil Validasi ahli materi

\begin{tabular}{ccc}
\hline Aspek & $\begin{array}{c}\text { Validator } \\
\mathbf{1}(\boldsymbol{\%})\end{array}$ & $\begin{array}{c}\text { Validator } \\
\mathbf{2 ( \% )}\end{array}$ \\
\hline Pendahuluan & 90 & 85 \\
Pembelajaran & 92 & 94 \\
Isi & 91.42 & 94.28 \\
Evaluasi & 85.71 & 91.42 \\
Rangkuman & 96 & 88 \\
\hline Rata-Rata & 91.02 & 90.54 \\
\hline
\end{tabular}


Berdasarkan hasil validasi ahli materi menunjukkan produk sudah baik dengan nilai angket diatas $85 \%$ dengan kriteria Validitas yaitu valid. Hal ini berarti materi sudah sesuai dengan kebutuhan dan dapat digunakan dalam pembelajaran Genetika, terutama pada materi Perubahan Materi Genetik. Modul dengan kecerdasan Intrapersonal dan Naturalis lebih ditekankan untuk mengakomodasi kebutuhan mahasiswa yang lebih dominan. Sedangkan modul dengan kecerdasan lain ditunjukkan sebagai upaya dalam mengembangkan kecerdasan tersebut, sehingga kejenuhan mahasiswa dapat dikurangi.

Hasil validasi ahli media dapat diketahui pada Tabel 3.

Tabel 4 Hasil Validasi ahli materi

\begin{tabular}{ccc}
\hline Aspek & $\begin{array}{c}\text { Validator } \\
\mathbf{1}(\boldsymbol{\%})\end{array}$ & $\begin{array}{c}\text { Validator } \\
\mathbf{2}(\boldsymbol{\%})\end{array}$ \\
\hline Fisik & 95.56 & 91.11 \\
Pendahuluan & 100 & 100 \\
Pembelajaran & 100 & 96 \\
Struktur & 100 & 100 \\
Tugas & 100 & 95 \\
Rangkuman & 100 & 96 \\
\hline Rata-Rata & 99.25 & 96.35 \\
\hline
\end{tabular}

Berdasarkan hasil validasi ahli media menunjukkan produk sudah baik dengan nilai angket diatas $91 \%$ dengan kriteria Validitas yaitu valid. Hal ini berarti media yang digunakan sudah sesuai jika berkaitan dengan aspek fisik, pendahuluan, pembelajaran, struktur, tugas dan rangkuman.

Penggunaan modul interaktif berbasis Multiple Intelligences dengan menggunakan Autoplay dalam pembelajaran sudah layak digunakan dalam pembelajaran di materi Perubahan Materi Genetik di IKIP Budi Utomo. Adanya modul diharapkan dapat mempermudah proses pembelajaran terutama dalam mempelajari materi Perubahan Materi
Genetik. Hal ini sejalan dengan Anantyarta dan Sari (2017) yang menyatakan bahwa media pembelajaran yang baik adalah media pembelajaran yang mampu mempermudah pendidik dalam menjalankan kegiatan pembelajaran. Kemudahan mahasiswa dalam menggunakan media juga sangat diperhatikan karena tidak mungkin kita memaksakan media pembelajaran tertentu sementara mahasiswa tidak tertarik atau berminat dalam mempelajarinya. Lebih lanjut, adanya media pembelajaran dalam kegiatan pembelajaran akan membantu mahasiswa dalam mengolah informasi yang biasanya disampaikan dalam bentuk verbal menjadi ke bentuk lain yang dapat lebih mudah dipahami sesuai dengan karakter siswa.

\section{SIMPULAN DAN SARAN Simpulan}

Produk hasil pengembangan ini dikembangkan melalui model pengembangan 4D yang terbatas pada Define, Design dan Develop. Produk yang dikembangkan berupa modul Interaktif berbasis Multiple Intelligence dengan Autoplay pada konsep perubahan materi genetik yang valid.

\section{Saran}

Perlu untuk dilakukan uji coba skala klasikal untuk mengetahui efektifitasnya dalam pembelajaran. Selain itu perlu adanya pelanjutan tahap pengembangan yaitu tahap diseminasi untuk menjadikan model penelitian dan pengembangan yang utuh.

\section{DAFTAR PUSTAKA}

Alfan, M \& Sulistiyo, E. 2015. Perbandingan Media Pembelajaran (Autoplay Media Studio) Sebagai Alat Bantu Pembelajaran Memperbaiki CD Player Siswa Kelas Xi Di Smk Negeri 3 Surabaya. Jurnal 
Vol. 3, No. 2 : Hal 30 - 36

Edisi September 2018

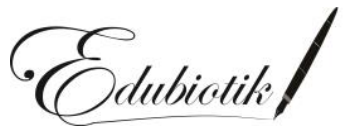

P-ISSN : 2528-679X

E-ISSN :2597-9833

Pendidikan Teknik Elektro. 4 (1): Setiawan,

D. 2012. Pengembangan $39-47$.

Instrumen Penulisan Jurnal Belajar

Anantyarta, P \& Sari, RLI. 2017. Pengembangan Media Auto Play dengan Metode Means Ends Analysis (MEA) pada Matakuliah Genetika. Makalah disajikan dalam Seminar Pendidikan IPA Pascasarjana UM.

Darmawan, N. 2016. Pengembangan Multimedia Interaktif Autoplay Pada Pembelajaran Biologi Materi Sistem Imun untuk Kelas XI SMAN 1 Lawang. Skripsi tidak diterbitkan, Malang: FMIPA UM.

Depdiknas. 2008. Pengembangan Bahan Ajar.

(Online)(http://dc218.4shared.com/d ownload/

vj4M9KIo/5_PENGEMBANGAN BAHAN_AJAR.rar?tsid $=20120227$ 061731-a8f2e27, diakses 20 Januari 2013).

Gardner, H. 2003. Multiple Intelligences: The Theory in Practice. New York: John Wiley.

Gardner, H. 2010. Multiple Intelligences. (Online)(http://www.howardgardner .com/MI/mi.html, diakses 17 Mei 2017).

Herawati, NI. 2018. Pengembangan Model Kurikulum Pendidikan Anak Usia Dini Berbasis Developmentally Appropiate Practice Untuk Menumbuhkembangkan Kecerdasan Interpersonal dan Kecerdasan Intrapersonal. Cakrawala Dini. (Online)( http://ejournal.upi.edu/index.php/ca krawaladini/article/viewFile/10374/ 6427).

Berbasis ICT (Information, Communication, Technology) pada Pembelajaran Biologi Siswa Sekolah Menengah Atas. Skripsi tidak diterbitkan. Malang: FMIPA UM.

Setyowati, Dwi Meinani \& Hinduan, Achmad A. 2009. Penerapan Kecerdasan Majemuk untuk Meningkatkan Hasil Belajar Fisika Peserta Didik di SMAN 2 Magelang Jawa Tengah. Berkala Fisika Indonesia. 1 (2): 27 - 31.

Sungkono. 2015. Pengembangan Instrumen Evaluasi Media Modul Pembelajaran. Majalah Ilmiah Pembelajaran, 2.

Thiagarajan, S., Semmel, D. S \& Semmel, M. I. 1974. Instructional Development for Training Teachers of Expectional Children. (http://www.eric.ed.gov/, diakses 1 Maret 2012).

Wena, M. 2009. Strategi Pembelajaran Inovatif Kontemporer. Jakarta: Bumi Aksara

36 Khoirun N. \& Deny S. - Pengembangan Modul Interaktif Berbasis Multiple ... 